\title{
14 Social Enterprise Approaches in Switzerland
}

\author{
Michaël Gonin, Nicolas Gachet and \\ Philipp Erpf ${ }^{1}$
}

\section{Introduction $^{2}$}

Switzerland's specific position at the crossroads of the German, French and Italian cultures results in a complex and rather segmented field of social enterprise (SE). Language and cultural barriers often make it difficult for actors across the country to collaborate and institutionalise a nation-wide understanding of the concept. There are many nation-wide umbrella structures with different approaches of social enterprise; moreover, these structures are often rather weak and sometimes separated into German and Romance-language structures, leading to a high diversity of definitions.

Originally, the SE concept in the Swiss context referred mainly to work-integration social enterprises (WISEs) and, by extension, to some social-work organisations with a business activity (e.g., second-hand shops). In the past years, though, international trends have led to a much broader use of the SE concept. In Western Switzerland, the French influence of the social and solidarity economy (SSE) movement gives a specific orientation to the emerging SE research, while the commongood, non-profit and volunteering approaches dominate the Germanspeaking research in the country. Consequently, and although both approaches are permeated by the social-entrepreneurship movement, ${ }^{3}$ no unified terminology exists in Switzerland, and a multitude of terms are used in relation to these actors, such as civil society, associations' sector, intermediary organisations, public-utility organisations, non-business organisations, non-governmental organisations (NGOs), social sector or voluntary sector (Helmig et al. 2009).

The confusion is maintained through specific characteristics of Swiss politics. The subsidiarity principle implies that any task falls de principio under the responsibility and authority of the cantons, unless an explicit constitutional article assigns the responsibility for it to the federal government. ${ }^{4}$ As a result, important domains such as social policies, public health and economic promotion are managed extensively by the cantons; and in the absence of a unifying legal framework for social enterprise, a 
diversity of local approaches and practices can be observed among social enterprises, in SE networks (where local networks exist) and in government support. Most umbrella organisations are organised around specific themes (microfinance, local agriculture, work integration, etc.) rather than around specific understandings of the third sector or of social enterprise.

The not-for-profit vs. for-profit differentiation requires additional clarification. Very often, the notions of "business", "economic objectives" or even "management" are conflated, in the view of third-sector actors, with the for-profit character, whereas non-profit is assimilated with "non-commercial". In this perspective, the third sector only includes traditional associations and foundations. These organisations can hire staff, produce goods and services, and innovate, but they secure their budget through donations, subsidies (nowadays increasingly through public procurement) and grants-not through attempting to sell their goods or services to other private actors or to the state as "customer". With this interpretation of the third sector, which is prevalent in most studies on the subject in Switzerland (e.g., Helmig et al. 2009), hybrid actors, with commercial and social mindsets-typically social enterprises-become difficult to "locate" on the field, as they are too "economic" for the third sector and too "social" for the business world.

In line with the EMES approach to social enterprise used as a frame of analysis in the ICSEM Project, we use the word economic in a broad sense to refer to paid staff, continuous production and a risk component.

The general structure of this contribution is the following: First, the traditional, third-sector approach to social enterprise is explained. Then, three SE approaches influenced by models from other countries are discussed, namely the social and solidarity economy, the economy for the common good and the social-entrepreneurship approaches. We end this contribution by highlighting two main challenges raised by these three approaches.

\subsection{The Traditional Third-Sector Approach to Social Enterprise}

While social enterprises are often seen as part of the third sector, some third-sector actors do not show the economic orientation necessary to qualify as social enterprise. In addition, most public-support measures to the field are still oriented towards the third sector in its older understanding, and not specifically towards social enterprise. Furthermore, while public authorities support third-sector organisations through various means, there is no overarching policy that would provide a unified conceptual framework and coordinate the various measures, which are taken mainly by the towns and the cantons. Most of the demands made by members of cantonal or national parliaments to boost 
the third sector and the social economy have been rejected by the respective chambers, and only few cantonal governments have specifically invested in this field, even though some cantonal constitutions mention the importance of associations and of support to these organisations. ${ }^{5}$ Interventions usually rather focus on specific domains: organisations active in the domains of culture, sports, child care, migrant populations, etc. are supported by a diversity of departments and services at various levels.

Nevertheless, despite the multitude of terms and the complexity of public policies, there seems to be a consensus that the third sector is clearly distinct from the state and from the business world. Switzerland has a long history of local associations and groups providing many services to society. In addition to serving their members' interest, these organisations play a central role in tackling many social needs identified by community members. Home-care services, cultural associations, local sports clubs and other social services are provided by local associations that show high independence from the local, regional or national governments. Switzerland also has a long tradition of volunteering and civic engagement, coupled with a culture of a rather limited state, be it municipal, cantonal or national (Stadelmann-Steffen et al. 2010).

The result of all this is that the Swiss third sector has long been equated with non-profit organisations (NPOs). It is composed of a variety of mainly local NPOs, with only a few bigger players (mainly those originally related to confessional organisations). And unlike what is the case in other countries, these bigger players have not imposed an oligopoly situation. The absence of oligopoly is further maintained through the weakness of umbrella structures; these often remain "federations of local groups" in which the latter keep their autonomy for most decisions and actions. Until recently, top-down management remained the exception, even among bigger structures. However, despite the small number of large organisations, the non-profit sector nevertheless represents about $5 \%$ of the gross domestic product and of the jobs in the country. In addition, formal volunteering in NPOs added up to 224 million hours in $2016,{ }^{6}$ surpassing the equivalent of 80,000 fulltime jobs previously estimated by Helmig et al. (2010). Most of the actors within this sector are foundations and associations.

In the last three decades (1990s-2010s), the business vs. third sector distinction has however been challenged by public-policy changes related to the new public management (NPM) trend. The NPM overhauled the functioning of the public administration as well as its relations to service providers, especially those in the social sector. As a result, public/ private partnerships based on public procurement procedures have become standard, pushing NPOs to become more entrepreneurial and competitive in their relation to the state and to each other. This evolution is not seen as a blessing by some third-sector actors, especially when 


\section{Gonin, Gachet \& Erpf}

short-term public procurement contracts, including narrowly defined requirements in terms of performance measurement, replace former long-term, privileged relations with public actors. Many smaller organisations relying to a significant extent on volunteering struggle to compete with bigger, sometimes for-profit organisations that have a higher paid/unpaid staff ratio, are better structured and labelled, and do not necessarily see an opposition between social work and competition. For these smaller organisations, the NPM shift is more imposed than embraced, and it is perceived as a threat to solidarity and to high-quality social work. Consequently, many actors implement the required changes reluctantly and in rather superficial manners (Battaglini and Dunand 2005; Perrot et al. 2006). They use the NPM language in tenders and reporting with the state, but they do not undergo a real organisational culture change to embrace the entrepreneurial mindset.

\subsection{New Approaches to Social Enterprise}

Three SE approaches coming from other countries are currently challenging traditional definitions and are therefore important to take into account when attempting to evaluate the future use of the SE concept in Swiss politics, research and practice. These are the French "social and solidarity economy" (économie sociale et solidaire, hereafter referred to as SSE), the German "economy for the common good" (GemeinwohlÖkonomie, ECG), and the "social-entrepreneurship" trend, coming from the US and UK. These three new trends are summarised in figure 14.1, and they are discussed in the following sections. Table 14.1 provides an overview of these three new approaches in light of the EMES indicators defining the ideal-typical social enterprise.

\subsubsection{Social Enterprises as SSE Organisations}

The concept of social and solidarity economy (SSE) has a long tradition in various countries, such as neighbouring France. However, in Switzerland, this terminology was seldom used until the creation of the Geneva Chamber of Social and Solidarity Economy (APRÈS-GE) in 2004. Following this, two other chambers were created, respectively, in the canton of Vaud and in the Bern-Jura-Neuchatel area. However, while the APRÈS-GE has become an established actor of the socio-political and economic life of the Geneva area, the concept remains only weakly established outside Geneva and is still totally unknown in the Germanspeaking part of the country. The references to the SSE theory, terminology and philosophy are mainly defended by Romance-language authors, and the links to existing international networks also mainly bring together Romance-language members, making an expansion in the German-speaking part of the country difficult. 

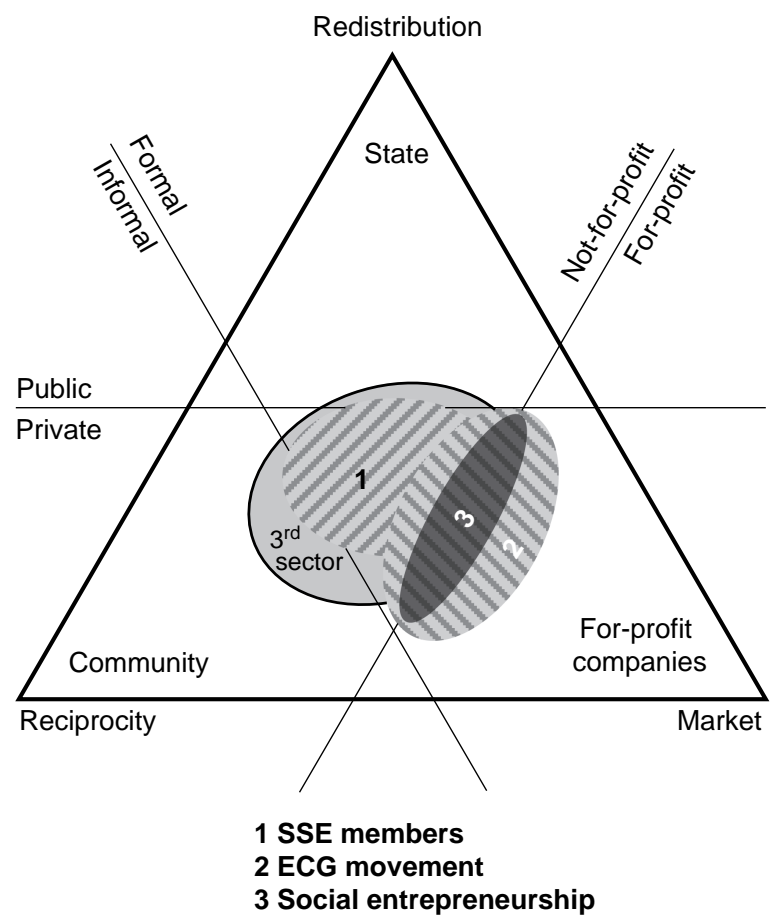

Figure 14.1 Positioning of the three SE approaches derived from current approaches.

Even though the concept remains unknown for the majority of the population, various studies show that actors that would correspond to the definition of the SSE represent an important part of the country's local economy and employment. ${ }^{8}$ Two Swiss SSE chambers benefitted from an EU Interreg funding to collaborate with SSE chambers in two neighbouring French areas. Nevertheless, this seemed not to suffice to make the SSE a widely acknowledged economic model and to create an SSE network for the entire Western Switzerland. A study of the definition and criteria of APRÈS-GE (that serves as the basis for the definition adopted by the other chambers) shows an interesting combination of the traditional definition of the SSE in France, the EMES indicators and a "Swiss twist" (Baranzini and Swaton 2013). The chambers, for instance, do not use the legal form as a criterion for accepting or refusing new members, but they rather verify whether core principles, such as participative governance and contribution to social welfare, are respected in the spirit of the organisation. This approach based on principles and criteria can lead to the inclusion of some corporations (which, in Switzerland, might apply to be recognised as not-for-profit in some situations) as well as to 


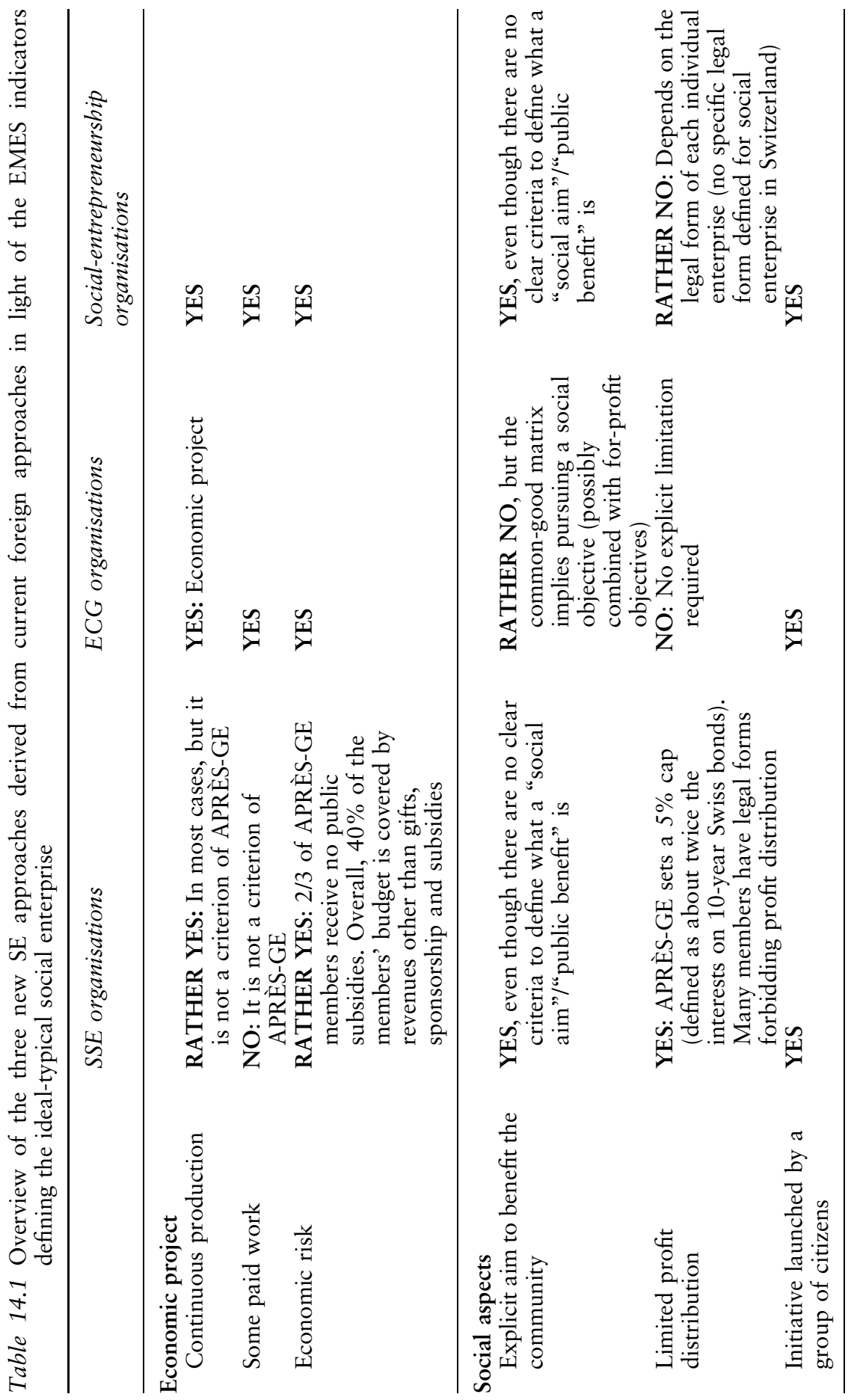




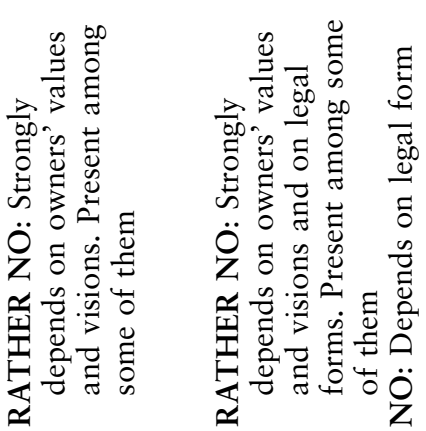

离
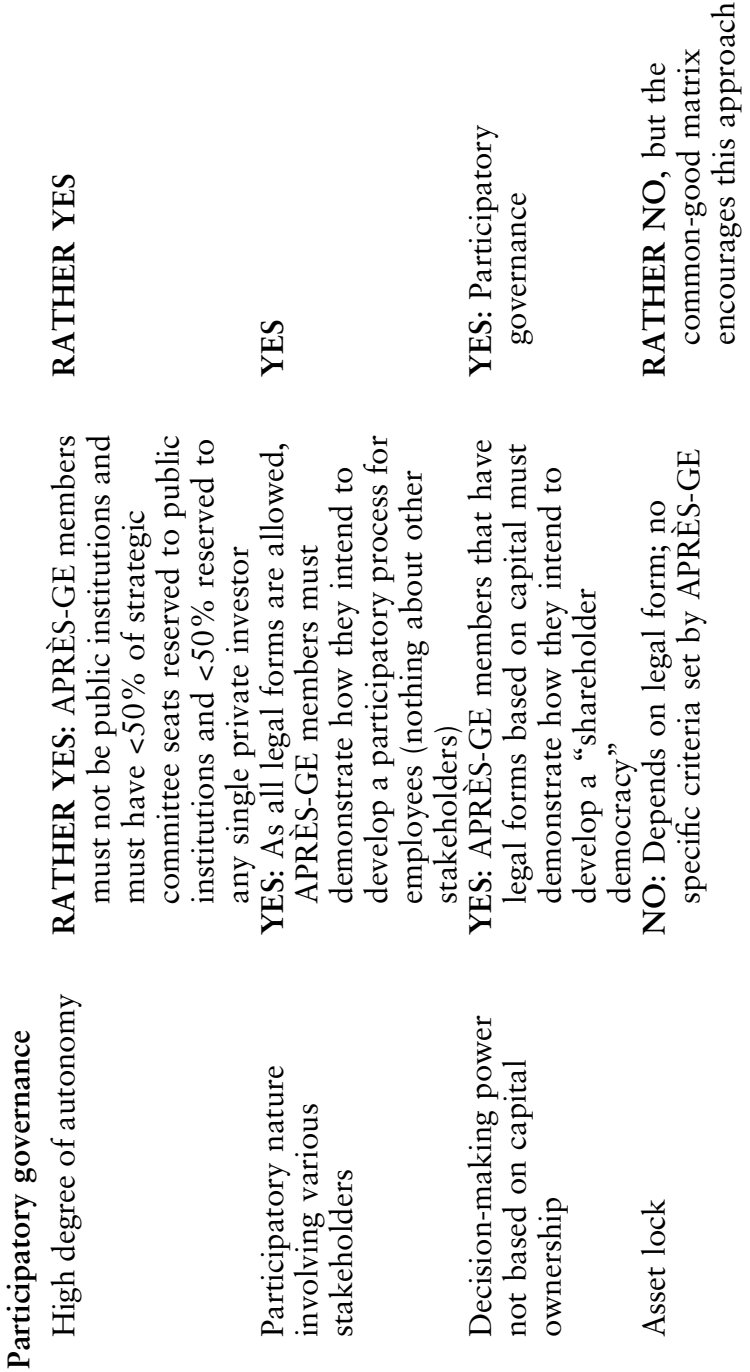


\section{Gonin, Gachet \& Erpf}

the possible exclusion of some associations, cooperatives and foundations that would have been included, had a "legal" definition of the field been used. It is also worth noting that (limited) profit distribution is better accepted within the Swiss SSE movement than in other SSE movements, which brings them closer to the social-entrepreneurship movement than to the French SSE, for instance.

APRÈS-GE's charter defines seven principles: social well-being ("to be, not to have"); participative citizenship and democracy ("each voice counts"); ecology ("produce to live, don't live to produce"); autonomy ("autonomous but not individualistic"); solidarity (" $1+1>2$ "); diversity ("rich in our differences"); and coherence ("say what we do and do what we say"). ${ }^{9}$ These principles have been refined in a series of criteria that are summarised in table 14.1 against the EMES indicators defining the ideal-typical social enterprise. While the economic dimension seems to be secondary in the criteria of APRÈS-GE (continuous production and paid work do not represent formal criteria, and although most members bear some economic risk, there is no "requirement" to do so), the social dimension is more explicit. Indeed, there must be an explicit social aim, profit distribution must be limited and transparency about profit distribution must be ensured, ${ }^{10}$ and a private initiative must be at the origin of the creation of the organisation. This focus on the social dimension might be the result of the influence of the third-sector approach that dominated in Switzerland. Anecdotical evidence for this is given by the fact that many members of APRÈS-GE come from the third sector. As for participatory governance, the degree of autonomy is an important criterion, and organisations that are directly submitted to public or private structures cannot become members of the chamber. Moreover, the participatory nature is encouraged as member organisations must demonstrate how they intend to develop the participatory process for their employees. Nevertheless, as all legal forms are allowed (including limited-liability companies and self-employed persons), participatory governance is not legally guaranteed, and it is moreover formally focusing on employees-even though APRÈS-GE promotes a broader understanding of stakeholder involvement. Finally, members (including those having legal forms based on capital) must provide the APRÈS-GE management committee with a self-assessment and with information about how they plan to meet their chamber's criteria within 2 years. ${ }^{11}$

This approach, based on principles and practices, allows for more flexibility than approaches based on legal forms, and it also challenges associations, cooperatives and foundations that do not necessarily respect all the principles despite their "SSE legal form". This allows for the integration of a multitude of actors that share most of the SSE values without necessarily having explicitly thought about it when they were created (as the SSE concept was not explicitly discussed in Switzerland until the 2000s). Nevertheless, as the Chambers grow, and also due to 
the emergence of the social-entrepreneurship approach, the Chambers will have to make their criteria more precise. For example, the fact that the movement is rooted in the political and the third-sector conceptions of the SSE as participatory and striving for the common good rather than for profit makes some of its proponents very wary of the socialentrepreneurship approach, which does not insist as much on participation (see Swaton 2011).

\subsubsection{Social Enterprises as ECG Organisations}

The second movement, namely that of the "economy for the common good" (ECG), seems to be emerging from Austria and Germany; it is found mainly in the German-speaking part of Switzerland. The ECG concept relies on a common-good notion that is well known in the area. The importance of the common good and of the community members' contributions to the latter is strongly rooted in many areas of Swiss social and political life. Illustrations of this are numerous, even though specialisation and professionalisation are leading to a decay of this common-good-contribution habit. For example, part of the agriculture, especially in Alpine areas, functioned based on the "commons", as studied by Nobel Prize laureate Ostrom. The "militia mindset" prevails in the political system (officially, politicians are non-professional), in fire brigades and in the army. Beyond these more official and state-related functions, the service-for-the-common-good mindset can be observed among the many people volunteering in either formal or informal ways for the local community (Schön-Bühlmann 2011).

The ECG proposes a political and economic system (including a taxation reform) that would better take into account the (positive and negative) social contributions of each organisation. Like in the SSE movement, the concept of social enterprise, in the ECG perspective, does not refer to a specific field of activity but rather reflects a particular, holistic understanding of business/society relations. Proponents of the ECG movement aim at bringing together enterprises that are strongly embedded in the local community and that abide by ECG values and contribute to the common good as "Sozialunternehmen" ("social enterprises" in German). Some networks related to the ECG movement seem to be emerging, such as the "common-good-economy movement" (Gemeinwohl-Ökonomie; see Felber and Maskin 2015). Yet, as with SSE organisations, the use of this term to refer to this group of organisations and the organisations themselves are not well known outside the ECG movement; and unlike the SSE movement, the ECG movement seems to be still very small. Indeed, although it concerns various regions in the German-speaking part of Switzerland, with many local groups being created, these groups are small and little known in their respective geographic areas. Much like the social-entrepreneurship movement, and 


\section{Gonin, Gachet \& Erpf}

perhaps in contrast to the SSE movement, the ECG movement's main strength in terms of further growth lies in its more business-like language, which might better reach out to organisations in the mainstream economy that consider themselves as "businesses", in opposition to the often negatively connoted "social enterprises". The risk in this approach is however the dilution of the core values into some "CSR-washing".

The proximity to the traditional business sector implies that ECG social enterprises easily fulfil the three indicators put forward by the EMES Network to describe the economic dimension of initiatives. As far as the social dimension is concerned, the explicit aim of benefitting the community is replaced by a more general notion of contribution to the common good. While this notion seems less clear than those of public interest and social aim, the ECG evaluation matrix nevertheless offers a clear operationalisation of the concept, as well as a system to evaluate organisations in this regard, based on four core principles (human dignity; solidarity and social justice [including minimisation of dividends paid]; environmental sustainability; and transparency and co-determination) that are each applied to a broad array of stakeholders, including suppliers, investors, employees and business owners, customers and partners, as well as to the organisation's social environment (region, electorate, future generations, civil society, fellow human beings, animals and plants). ${ }^{12}$ Like the SSE chambers, the movement seeks to motivate its members to progress on these various dimensions-not all actors focus on the same dimensions at the beginning. The participatory governance is thus also valued by the model: Indeed, its "transparency and co-determination" principle includes criteria such as the inclusion, in decision-making processes, of employees (also for the election of managers) and of local stakeholders and NGOs.

While still young, the movement is not to be ignored, for multiple reasons. Firstly, the German-speaking part of the country represents about two-thirds of the population and hence might have more weight in national public policy than other parts of the country. ${ }^{13}$ Secondly, the ECG movement has international connections and is related to professors in the academia in several countries. Thirdly, it raises interest among traditional businesses seeking to enhance and promote their social dimension. Finally, the ECG mindset is strengthened through the parallel re-emergence of cooperatives, which are often considered as the prototypical hybrid, socio-economic organisational form. Cooperatives were the most used legal form for businesses in Switzerland at the end of the $19^{\text {th }}$ century, but they have lost much influence during the $20^{\text {th }}$ century; yet various cooperatives have been attempting to give a new impetus to this legal form since the 2008 financial crisis. Cooperatives include older banks and insurance companies, traditional housing cooperatives, as well as new, creative consumer cooperatives (or even mixed producer/consumer cooperatives) in all sectors of activities; in 
addition, some worker cooperatives emerged too (Gachet and Gonin 2013). A new umbrella organisation for large cooperative enterprises has recently been created (Interessengemeinschaft Unternehmensgenossenschaft, now idée coopérative) and signs point to emerging networks for smaller cooperatives.

\subsubsection{Social enterprises as Social-Entrepreneurship Actors}

While not nationally unified in a single movement, the socialentrepreneurship movement, which originated in the US and UK, shows some characteristics that suggest a potentially important impact on the Swiss SE field in the coming years. Actors in the SE ecosystem (entrepreneurs, foundations, academics, etc.), whatever the school of thought they refer to, use the concept of social entrepreneurship in one way or another and want to promote it.

Two major trends can be identified within the social-entrepreneurship movement. The first trend is observed among traditional third-sector organisations that develop commercial activities as a source of revenue for their social mission (see the review by Defourny and Nyssens 2010).

The second trend is the social-innovation trend, which insists on the innovation part rather than on the form of organisation (Drayton 2002). Socially entrepreneurial individuals can either be found within existing social enterprises or non-profit structures or start a new organisation, independently from existing structures. In both cases, what distinguishes these actors from the traditional non-profit sector is not so much their relation to the social issue they tackle as their relation to the entrepreneurial and commercial dimension of their project. While nonprofit organisations and the SSE are often in opposition to-or at least in tension with-the mainstream business sector, social entrepreneurs seek to overcome this dichotomous approach and combine social and entrepreneurial/business-oriented mindsets.

Both trends of the social-entrepreneurship movement are also present in Switzerland. Ashoka and the Schwab Foundation (with headquarter in Geneva) but also organisations such as Euforia, seif, the Social Impact Hubs and Social Business Models are developing various programmes to foster social entrepreneurship. In addition, Switzerland is playing a major role in the field of microfinance investment funds and sustainable finance (in its broadest sense), ${ }^{14}$ and while the pioneering funds were created within the traditional NPO world, new actors with commercial and profit-oriented intentions, closer to the social-entrepreneurship mindset, followed (e.g., BlueOrchard and ResponsAbility). ${ }^{15}$

As a consequence of social entrepreneurship's roots being closer to the business world than to non-profits, the economic and especially the entrepreneurial dimensions of social enterprises belonging to this trend are well developed. All three EMES indicators related to the economic 


\section{Gonin, Gachet \& Erpf}

dimension of initiatives are fulfilled. As far as social aspects are concerned, while social entrepreneurship implies an explicit social aim and results from a private initiative, the indicator about a limited profit distribution, submitted to a social aim, is debated within this trend. While some social entrepreneurs exclude any possibility of profit distribution, others consider a "reasonable" profit distribution as acceptable-without necessarily offering a clear definition of what would be reasonable. Finally, as regards participatory governance, autonomy is often very important among these social entrepreneurs, even though some social-impact investment funds and "social-business angels" are strongly involved in the development and strategy definition of the funded organisations. Participation and democratic decision-making remain however two dimensions that are not explicitly addressed in the social-entrepreneurship approach and are therefore often overseen, unless explicitly implemented by the actor. Nevertheless, some networks implement well-developed participatory governance systems, based for instance on models such as holacracy and sociocracy.

\subsection{Challenges}

The three SE approaches discussed in section 14.2 are challenging the traditional definitions referred to in section 14.1. The following section discusses two of these challenges for future research and practice in the field of social enterprise: (1) the blurring of SE boundaries and (2) the reshaping of the public-policy and research context.

\subsubsection{Blurry SE Boundaries and New Synergies}

The emergence of new approaches to social enterprise blurs the boundaries of the third sector/SE field. Among other implications, this evolution raises the question of actors located at the periphery of the field. For instance, many SMEs, though being, from the formal and legal point of view, for-profit enterprises, are locally embedded and want to remain local. Their involvement in the local community might, on some dimensions, locate them close to the third sector/SE field. It also appears that, conversely, some third-sector actors are located at the periphery of the SE world, either because they have only a social purpose but no real economic dimension or because their social objective is questioned by part of the population or even missing (some non-profit organisations clearly assert their primary intent of serving their members and not the common good).

Despite the theoretical challenges that such a redrawing of boundaries in more permeable terms implies, a discussion of the new boundaries allows for the development of new synergies that can be better exploited by various types of actors (Gonin and Erpf 2018). Further studies are 
required to clarify the context and evaluate whether the inclusion/exclusion of the various actors located at the periphery of the field would be appropriate or not. By actively seeking the involvement of SMEs in its networks, the ECG movement, for instance, opens the question of the relation of SMEs to social enterprise. More generally, while some SE-like SMEs would probably refuse to be called SEs, the three movements discussed here seem to lead slowly to new collaborations and the setting up of common platforms that include both traditional SMEs, social enterprises, and even traditional non-profits (see, e.g., Drayton and Budinich 2010). Regularly, collaboration platforms are organised locally in Switzerland to foster exchanges of expertise and collaboration between businesses and non-profits. More broadly, the development of the B-Corp label and the concept of hybrid value chain represent important growth factors and lead to changes within the business world and in the latter's relation to social enterprise. ${ }^{16}$

Even among actors clearly identified as social enterprises, some differences that arise are based more on differences in terminology or in the philosophical streams adhered to than on actual differences in practices. For instance, the evolution of the fair-trade movement points to the limits of clear-cut boundaries and predefined categorisations within the SE field. Indeed, this movement started within the traditional NPO world, with some associations selling a few fair-trade products (e.g., TerrEspoir, Magasin du Monde, Claro); it has since extended to the Max Havelaar fair-trade label, commercialised by the biggest Swiss retailers. In addition, some businesses have developed or joined industry-specific fair-trade labels, such as UTZ for chocolate, coffee and tea.

Finally, the study of the various approaches highlights that, while most criteria are fulfilled by the different SE approaches identified in this study, none of these approaches clearly fulfils the participatorygovernance indicators if this aspect is to include stakeholders beyond the members and/or the employees of the organisation. Formal participatory governance remains therefore an important challenge, whatever the approach considered (Gachet and Gonin 2015a). What seems essential however at this stage is the development of a clear definition of the "social aim", with a view to establishing a clear delineation of the SE field and distinguishing it from mainstream CSR, and from some social businesses and some third-sector actors promoting their own interests, which are not necessarily considered as "social aims" (see Gachet and Gonin 2015b). While the notions of common good and social aims are used by many movements and actors, and are widely mentioned in the literature, their exact definition indeed seems to remain an almost unaddressed issue among practitioners and scholars alike-as if these definitions could be "taken for granted". Yet important questions remain: Who is to define, and according to which rules, what is "social"? What is the cultural part of this definition, which seems to evolve over time? 


\subsubsection{Public-Policy and Research Context}

The second challenge lies in the fact that specific support from local governments for the SE field as such (regardless of the trend considered) is very limited and that no intercantonal coordination of such support seems to emerge. Public support is mainly indirect; it comes from the attribution of specific public procurements to social enterprises, and it is not intended to encourage a specific type of business, economic ideology or social-service structure. Such attitude, however, tends to favour a status quo in which burgeoning initiatives struggle to be recognised and to access public support or economic promotion, as the existing authorities do not necessarily make the effort to understand their specificities and find ways to accommodate them within the existing framework. An exception here is the increasing support provided by local authorities, mainly in the domain of housing cooperatives. The latter receive special access to land property to build affordable housing (see, e.g., the measures implemented in Lausanne and Geneva).

From a legal perspective, there is no specific legal form for social enterprise in Switzerland, and there is no project of creating one. Social enterprises are the result of practices and mindsets rather than of a structured legal framework or adhesion to a specific movement. This should not be considered as a tremendous problem, though, as the existing legal framework allows much freedom within the existing legal forms. Associations can have commercial activities, and corporations can be non-profit. Nevertheless, the typical hybrid form, namely that of cooperative, is currently neglected by agencies responsible for economic promotion, which do not know the specificities of this form and, consequently, do not promote it. Regularly, hybrid actors, such as cooperatives, complain that some laws (e.g., the banking law) do not take the specificities of the cooperative legal form into consideration and impose regulatory constraints which are not adapted to their specific legal form-either the law tackles an issue that is already implicitly solved by the legal form and, in so doing, still adds constraints and administrative burdens on the cooperative, which thus loses a competitive advantage, or its application in a cooperative is more burdensome than in a corporation and might even weaken the cooperative mindset.

In this context, instead of pushing for the creation of a rigid framework, the many burgeoning initiatives need to acknowledge their respective strengths and work together to strengthen the civil-society sector, which seems to suffer from the NPM and raising individualism.

As for research, there is no extensive and coordinated research project across SE approaches in Switzerland. Such a project might be a condition to increase the visibility and legitimacy of the SE field in general, beyond ideological boundaries and throughout the country, and to obtain substantive formal support from governments at the local, state and federal levels. 


\section{Conclusion}

In addition to the original conception of social enterprise in Switzerland, namely WISEs and, by extension, hybrid economic social-service actors, three new approaches contribute to making the SE concept both more visible and blurrier. On the one hand, the multiplication of definitions, criteria and umbrella structures makes it difficult to extract a full-yet coherent-definition of the sector that would allow social enterprise to gain specific support from authorities and increased legitimacy as a research field. On the other hand, this multiplication leads to increased visibility, which in turn fosters debates and challenges both traditional businesses and traditional NPOs to review their dichotomous conception of private actors, perhaps pulling many actors of these two spheres closer to the hybrid centre of social enterprise.

The most important conclusion from this study is that there is currently a shift in Switzerland from the original definition of social enterprise, confined to WISE, to a broader use, which included, in a first stage, other social-work organisations, and now also includes members of the three new movements observed in Switzerland, namely the SSE, the ECG and the social-entrepreneurship movements. Furthermore, we also observe a renewed interest, among various types of actors and industry sectors, for the cooperative form, because of its combination of economic and social characteristics.

\section{Notes}

1 All authors contributed equally to this chapter.

2 Due to length restrictions, only the main approaches and the main references are given in this chapter. A full version, including the development of the typology and detailed references and bibliography, can be found in Gonin and Gachet (2015).

3 "Social entrepreneurship" and "social entrepreneur" refer in this chapter to the specific movement that originated in the US/UK and that tends to dominate the literature in the Anglosphere.

4 Switzerland is a federal state composed of 26 states, called "cantons".

5 Interestingly, these constitutional provisions seem to focus on legal forms more than on a specific socio-economic approach. For example, the Constitutions of the Cantons of Vaud (art. 70) and Geneva (art. 211) state that associations are to be supported and volunteering promoted.

6 See detailed data of the Federal Statistical Office at https:// www.bfs.admin.ch/bfs/en/home/statistics/work-income/unpaid-work/ household-production-satellite-account.html.

7 The triangle opposes the three main Polanyian principles of economic exchange, namely market, redistribution and reciprocity, and it positions three different kinds of actor according to the extent to which they rely on these three principles for their operation: the state, which is mainly a redistributive institution; private for-profit companies, whose operation is mainly based on the market logic; and the community, which is mainly based on reciprocity. Three axes differentiate the resources and rationales on which these actors 
rely to develop their activities: formal $v s$. informal, public $v s$. private and notfor-profit $v s$. for-profit (Defourny and Nyssens 2012).

8 See Chambre de l'économie sociale et solidaire Après-GE (2010, 2015), as well as Gachet and Gonin (2015b).

9 See http://apres-ge.ch/node/32136 and http://apres-ge.ch/node/34120.

10 This transparency is however limited, as the organisation can choose to have its financial reports examined by a fiduciary that certifies the fulfilment of the criteria, rather than submitting its reports to the APRES-GE management committee or to the public at large.

11 The criteria of transparency, collective interest/collective good, autonomy and limited profit must be met in order to join APRÈS-GE. The criteria of respect for the environment, participatory management and social management may not be fully met upon entry. In this case, organisations have 2 years to comply with them.

12 See the full matrix at https://www.ecogood.org/en/our-work/common-goodbalance-sheet/common-good-matrix/.

13 However, the subsidiarity principle mitigates any vision of a nationally enforced SE policy, and implies that regional differences will always remain.

14 Thirty-four percent of worldwide microfinance assets are managed by funds located in Switzerland (Symbiotics Research \& Advisory S.A., 2018; see also networks such as Sustainable Finance in Geneva). In addition, networks such as the network wise impact the philanthropy field by promoting impact-oriented philanthropy (see https://www.ville-geneve.ch/actualites/detail/article/1570091187building-bridges-semaine-finance-durable-geneve/).

15 In some cases, these funds have even put the profit objective above the social ones, causing tremendous damages among those who should have benefitted from these funds (see publications by Jean-Michel Servet [Graduate Institute, Geneva] and the Centre for Sustainable Finance and Private Wealth [University of Zurich]).

16 See https://www.bcorp-switzerland.ch, https://bestforgeneva.ch as well as Drayton and Budinich (2010) and Porter and Kramer (2011).

\section{References}

Baranzini, L. \& Swaton, S. (2013) "Définir la nouvelle économie sociale par les critères plutôt que par les statuts? Une analyse théorique à partir des critères retenus en Suisse par APRÈS-GE”, in Defalvard, H., L'Horty, Y., Legendre, F. \& Narcy, M. (eds) Les nouvelles frontières de l'économie sociale et solidaire, Louvain-la-Neuve: Presses universitaires de Louvain.

Battaglini, M. \& Dunand, C. (2005) "Les relations entre État et associations: Quels modèles pour quelles relations?”, Bulletin de La FEAS, Vol. 2, pp. 12-21.

Chambre de l'économie sociale et solidaire Après-GE (2010) Etude statistique. Photographie de l'économie sociale et solidaire à Genève, Geneva: Chambre de l'économie sociale et solidaire Après-GE.

Chambre de l'économie sociale et solidaire Après-GE (2015) Panorama de l'économie sociale et solidaire à Genève. Étude statistique 2015, Geneva: Chambre de l'économie sociale et solidaire Après-GE.

Defourny, J. \& Nyssens, M. (2010) "Conceptions of social enterprise and social entrepreneurship in Europe and the United States: Convergences 
and divergences", Journal of Social Entrepreneurship, Vol. 1, No. 1, pp. 32-53.

Defourny, J. \& Nyssens, M. (2012) "The EMES approach of social enterprise in a comparative perspective", EMES Working Papers Series, No. 12/03, Liège: EMES International Research Network.

Drayton, W. (2002) "The citizen sector: Becoming as entrepreneurial and competitive as business", California Management Review, Vol. 44, No. 3, pp. 120-132.

Drayton, B. \& Budinich, V. (2010) "A new alliance for global change", Harvard Business Review, Vol. 88, No. 9, pp. 56-64.

Felber, C. \& Maskin, E. (2015) Change Everything: Creating an Economy for the Common Good, London: Zed Books.

Gachet, N. \& Gonin, M. (eds) (2013) La coopérative, un modèle d'avenir? Colloque interdisciplinaire sur le présent et devenir des coopératives en Suisse romande, Lausanne: Université de Lausanne, projet ESS-VD.

Gachet, N. \& Gonin, M. (eds) (2015a) La gouvernance participative dans les coopératives. Colloque interdisciplinaire sur les défis et les bonnes pratiques en matière de gouvernance participative, Lausanne: Université de Lausanne, projet ESS-VD.

Gachet, N. \& Gonin, M. (2015b) Spécificités et contributions de la nébuleuse de l'économie sociale et solidaire. Une réflexion à partir du contexte vaudois, Lausanne: Université de Lausanne, projet ESS-VD.

Gonin, M. \& Erpf, P. (2018) "Sinnfindung und Sinngebung jenseits von Sektorendenken", in Gmür, M., Andessner, R., Greiling, D. \& Theuvsen, L. (eds) Wohin entwickelt sich der Dritte Sektor. Konzeptionelle und empirische Beiträge aus der Forschung, Fribourg: Verbandsmanagement Institut VMI, pp. 135-140.

Gonin, M. \& Gachet, N. (2015) "Social enterprise in Switzerland: An overview of existing streams, practices and institutional structures", ICSEM Working Papers, No. 03, Liège: The International Comparative Social Enterprise Models (ICSEM) Project. Available HTTP: http://www.iap-socent.be/sites/ default/files/Switzerland\%20-\%20Gonin\%20\%26\%20Gachet_0.pdf.

Helmig, B., Bärlocher, C. \& von Schnurbein, G. (2009) "Defining the nonprofit sector: Switzerland", Working Papers of the Johns Hopkins Comparative Nonprofit Sector Project, No. 46, Baltimore: The Johns Hopkins Center for Civil Society Studies.

Helmig, B., Lichtsteiner, H. \& Gmür, M. (eds) (2010) Der dritte Sektor der Schweiz. Länderstudie zum Johns Hopkins Comparative Nonprofit Sector Project (CNP), Bern: Haupt.

Perrot, M.-D., DuPasquier, J.-N., Joye, D., Leresche, J.-P. \& Rist, G. (eds) (2006) Ordres et désordres de l'esprit gestionnaire: où vont les métiers de la recherche, $d u$ social et de la santée, Lausanne: Editions Réalités sociales.

Porter, M. E. \& Kramer, M. R. (2011) "Creating shared value", Harvard Business Review, Vol. 89, No. 1/2, pp. 62-77.

Schön-Bühlmann, J. (2011) Le travail bénévole en Suisse en 2010, Report No. 425-1100, Neuchâtel: Office fédéral de la statistique. Available HTTP: https:// www.bfs.admin.ch/bfsstatic/dam/assets/348258/master. 
Stadelmann-Steffen, I., Traunmüller, R., Gundelach, B. \& Freitag, M. (2010) Freiwilligen-Monitor Schweiz 2010, Zürich: Seismo.

Swaton, S. (2011) Une entreprise peut-elle être "sociale" dans une économie de marché?, La Question, Charmey: L'hèbe.

Symbiotics Research \& Advisory S. A. (2018) 2018 Symbiotics Microfinance Investment MIV Survey, Market Data \& Peer Group Analysis, Geneva: Symbiotics. 